\title{
A Sensitive Fluorometric Method for the Determination of Glutathione and Some Thiols in Blood and Mammalian Tissues by High Performance Liquid Chromatograpby ${ }^{\dagger}$
}

\author{
Hiroaki Takahashi, Yasunori Nara, Hiroshi Meguro \\ and Katura Tuzimura \\ Laboratory of Analytical Chemistry, Department of Food Chemistry, \\ Faculty of Agriculture, Tohoku University, 1-I Tsutsumidori- \\ Amamiyamachi, Sendai 980, Japan \\ Received December 20, 1978
}

\begin{abstract}
A fluorescent reagent, $N$-(9-acridinyl)maleimide (NAM), was used for the determination of thiols in biological samples by high performance liquid chromatography. NAM-labeled glutathione (GSH), homocysteine, coenzyme A ( $\mathrm{CoA})$ and cysteine (CySH) were separated on a reversed-phase partition (octadecylsililated silica gel) column with the elution conditions of $0.06 \mathrm{M}$ borate buffer $\mathrm{pH} 8.8$ : methanol $(13: 1)$ at a flow rate of $0.6 \mathrm{ml} / \mathrm{min}$ within $15 \mathrm{~min}$. In the absence of $\mathrm{COA}$ in the sample, the elution conditions of $0.1 \mathrm{M}$ borate buffer $\mathrm{pH} 8.8$ : methanol $(15: 1)$ at a flow rate of $0.8 \mathrm{ml} / \mathrm{min}$ was used for the separations. Calibration curves were held up to $2.5 \mathrm{pmol}$ for GSH and $11 \mathrm{pmol}$ for CySH. About $0.17 \mu \mathrm{l}$ of rat blood and $0.03 \mathrm{mg}$ of rat liver equivalent to $0.1 \mathrm{nmol}$ of GSH were determined. The sensitivity was 100 times higher than that obtained with an automatic amino acid analyzer.
\end{abstract}

Thiols such as glutathione (GSH), cysteine (CySH) and coenzyme A (CoA) occur widely among living tissues and blood. Total and/or separate analytical methods for these thiols are reviewed. ${ }^{1 \sim 3)}$ Among them, the 5,5'dithiobis(2-nitrobenzoic acid) (DTNB) ${ }^{4}$ and $\mathrm{N}$-ethylmaleimide (NEM) ${ }^{5}$ ) methods have been most commonly used.

A separate assay for GSH, CySH and their related compounds has been carried out on an amino acid analyzer. ${ }^{6)}$ A mercury-based electrochemical detector has also been designed for the selective detection of sulfur-containing compounds such as CySH and GSH." However, their sensitivities are not satisfactory for a small amount of samples.

Previously we reported a sensitive and specific fluorescent determination of thiols with $N$-(9-acridinyl)maleimide (NAM) ${ }^{8}{ }^{8}$ However, the method was used only to determine total thiols, and the development of an individual determination was necessary. Recently a high performance liquid chromato-

${ }^{\top}$ The study was supported by the grant from the ministry of Education of Japan. graph (HPLC) has become a powerful separating equipment in various fields. Here we reprot a new and sensitive determination of $\mathrm{GSH}, \mathrm{CySH}$ and $\mathrm{CoA}$ by the separation of the NAM-labeled thiols on HPLC.

\section{MATERIALS AND METHODS}

Reagents. (a) NAM solution; NAM was synthesized according to the previous papers..$^{0.10)}$ It was dissolved in acetone of the analytical grade for fluorescence spectrometry (Wako Pure Chemical Co.). (b) Standard sample solution; GSH, CySH and homocysteine (HomoCySH) were purchased from Wako Pure Chemical Co. They were dissolved in $0.02 \mathrm{M}$ disodium ethylenediaminetetraacetate dihydrate (EDTA). (c) Internal standard solution; 6-amino1,3-naphthalene disulfonate (ANS) was purchased from Wako Pure Chemical Co. and dissolved in distilled water. (d) Reaction medium and elution buffers; pH 8.8 borate carbonate buffers $(0.5,0.1$, $0.06 \mathrm{M}$ ) were prepared by titrating boric acid-potassium chloride solutions $(0.5,0.1,0.06 \mathrm{M})$ with sodium carbonate solutions of equimolar concentrations $(0.5$, $0.1,0.06 \mathrm{M})$. The buffer $(0.5 \mathrm{M})$ was used as the reaction buffer.

High performance liquid chromatography. The high performance liquid chromatography was carried 


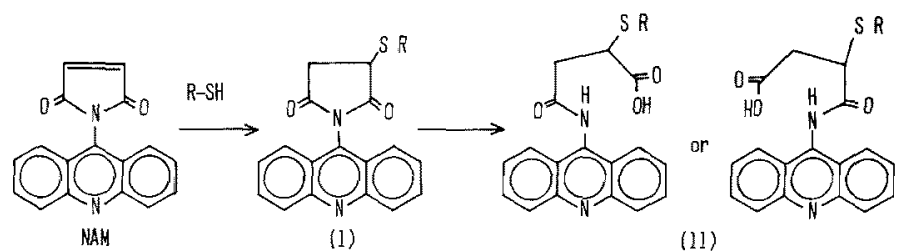

Scheme. Reaction Mechanism of Thiols with NAM.

out on a JASCO FLC-150 equipped with a stainless column $(50 \mathrm{~cm} \times 2.3 \mathrm{~mm}$ I.D., JASCOPACK SV-02500) packed with octadecylsililated silica gel (Vydac, $25 \sim 35 \mu \mathrm{m})$ as a reverse-phase partition chromatographic separation material. The eluents were a mixture of methanol (MeOH) of a HPLC grade (Wako Pure Chemical Co.) and borate carbonate buffers $(0.06$, $0.1 \mathrm{~m} \mathrm{pH} \mathrm{8.8).} \mathrm{The} \mathrm{injections} \mathrm{were} \mathrm{performed} \mathrm{with} \mathrm{a}$ micro-syringe (Terumo) through a silicon septum on the top of the column. Fluorescence measurements were made by the excitation at $360 \mathrm{~nm}$ with a Xe lamp and the emission at $435 \mathrm{~nm}$ at $23 \pm 1^{\circ} \mathrm{C}$ on a JASCO FP-4 Fluorescence Spectrophotometer equipped with a flow cell of $10 \mu$ volume. The fluorescence intensities were recorded on a Model DR Desktop Recorder (Okura Electric Co.) with a chart speed of $2 \mathrm{~mm} / \mathrm{min}$.

\section{RESULTS AND DISCUSSION}

\section{Fluorescence labeling of thiols with NAM}

The reaction mechanisms were discussed in the previous paper. ${ }^{10}$ ) The thiols added to a double bond of maleimide moiety immediately form the succinimide (I) moiety which was gradually hydrolyzed to secondary products (II) (Scheme). Figure 1 shows the time course of the fluorescence development of NAM-labeled thiols at $\mathrm{pH}$ 8.8. Here two types of labeling reactions should be differentiated. (1) GSH type; GSH, HomoCySH and $\mathrm{COA}$ reacted $\mathrm{NAM}$ to form an addition product (I) and then hydrolyzed quantitatively forming (II) which gave a different peak with a longer retention time $(R t)$. After $2.5 \mathrm{hr}$ the peak (I) was completely replaced by the peak (II) which was stable for $24 \mathrm{hr}$. (2) CySH type; CySH also formed an addition product (I).' Howvere, the rate of the hydrolysis of (I) to (II) was practically negligible at least for $15 \mathrm{hr}$. Therefore, the reaction time can be allowed from $2.5 \mathrm{hr}$ to $15 \mathrm{hr}$ in the determination. (Note; the fluorescence labeling reaction at a higher $\mathrm{pH}$ showed a little

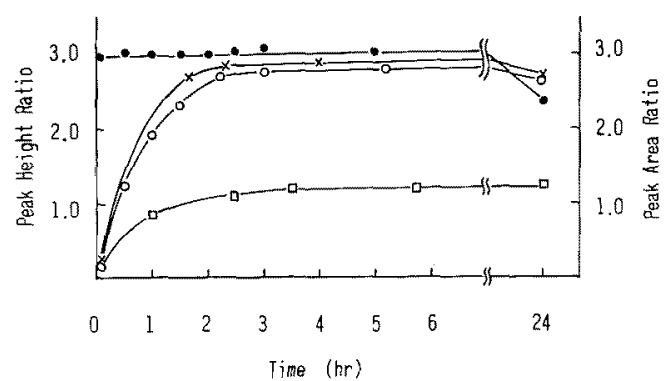

Fig. 1. Time Course of the Fluorescence Development of Thiols during the Reaction with NAM.

Solutions of thiols $(0.2 \mathrm{ml}, 0.1 \sim 0.3 \mu \mathrm{mol})$ were added to $0.55 \mathrm{ml}$ of the reaction buffer and then $0.05 \mathrm{ml}$ $(0.1 \mu \mathrm{mol})$ of ANS and $0.2 \mathrm{ml}(0.5 \mu \mathrm{mol})$ of NAM were added. Aliquots $(5 \sim 10 \mu 1)$ of the reaction mixtures were injected on the HPLC with the passage of time. The peak height ratio of GSH $(O, 0.15 \mathrm{nmol})$ and HomoCySH $(\times, 0.31 \mathrm{nmol})$ to ANS and the peak area ratio of $\mathrm{CySH}(\square, 0.10 \mathrm{nmol})$ and $\mathrm{CoA}(\bullet, 0.23$ nmol) to ANS were plotted. The relative height ratio arbitrarily shows only time course and do not show the relative fluorescence intensities of the NAMlabeled thiols.

weaker fluorescence although it reached the constant value faster than at $\mathrm{pH} 8.8$ ).

\section{Separation on HPLC}

The possible thiols in mammalian tissues are GSH, CySH, CoA and HomoCySH. The following two standard mixtures were examined after pre-labeling reaction with NAM. (A); a mixture of GSH, CoA and CySH. (B); a mixture of GSH, HomoCySH and CySH. ANS was used as an internal standard which had a fluorescence emission maximun at $465 \mathrm{~nm}$ and an exitation at $355 \mathrm{~nm}$ in $0.1 \mathrm{M}$ borate buffer $\mathrm{pH} 8.8$.

The following elution conditions were selected after preliminary trials. Elution condition (I); $0.06 \mathrm{M}$ borate carbonate buffer $\mathrm{pH}$ 8.8: $\mathrm{MeOH}(13: 1)$ at a flow rate of $0.6 \mathrm{ml} / \mathrm{min}$. 


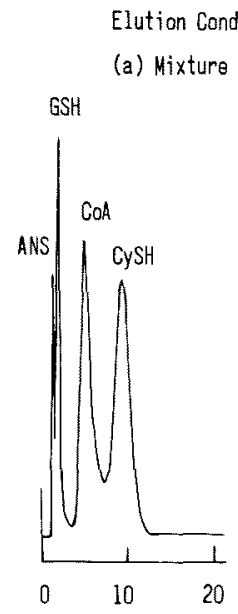

(b) Mixture (8)

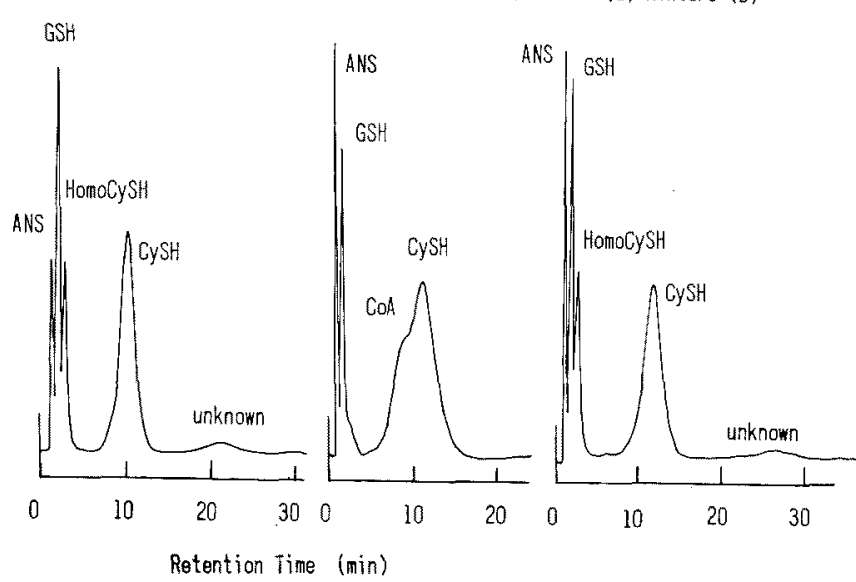

Elution Condition (11)
(c) Mixture (A)
(d) Mixture (B)

Fro. 2. High Performance Liquid Chromatograms of NAM-Labeled Thiols.

Reaction mixture (A); To $1.9 \mathrm{ml}$ of the reaction buffer, $0.02 \mathrm{ml}(0.04 \mu \mathrm{mol})$ of GSH, $0.08 \mathrm{ml}$ $(0.10 \mu \mathrm{mol})$ of CySH, $0.4 \mathrm{ml}(0.38 \mu \mathrm{mol})$ of CoA, $0.03 \mathrm{ml}(0.09 \mu \mathrm{mol})$ of ANS and $0.27 \mathrm{ml}(0.84$ $\mu \mathrm{mol})$ of NAM were added. Reaction mixture (B); To $1.53 \mathrm{ml}$ of the reaction buffer, $0.05 \mathrm{ml}$ $(0.11 \mu \mathrm{mol})$ of GSH and HomoCySH, $0.15 \mathrm{ml}(0.20 \mu \mathrm{mol})$ of CySH, $0.02 \mathrm{ml}(0.06 \mu \mathrm{mol})$ of ANS and $0.20 \mathrm{ml}(0.62 \mu \mathrm{mol})$ of NAM were added. After standing for $3 \mathrm{hr}$, aliquots $(5 \sim 10 \mu \mathrm{l})$ of these reaction mixtures were injected. Amounts of injection were from 0.17 to 0.93 nmol. Elution condition (D); borate buffer $(0.06 \mathrm{M}, \mathrm{pH} 8.8): \mathrm{MeOH}=13: 1$ at a flow rate of $0.6 \mathrm{ml} / \mathrm{min}$ [(a), (b)]. Elution condition (II); borate buffer $(0.1 \mathrm{M}, \mathrm{pH} 8.8): \mathrm{MeOH}=15: 1$ at a flow rate of $0.8 \mathrm{ml} / \mathrm{min}$ $[(\mathrm{c}),(\mathrm{d})]$.

Elution condition (II); $0.1 \mathrm{M}$ borate carbonate buffer $\mathrm{pH} 8.8$ : MeOH $(15: 1)$ at a flow rate of $0.8 \mathrm{ml} / \mathrm{min}$. Here the flow rates were selected to get the best separation in the shortest time. Under these conditions, ANS was eluted at the solvent front and NAM-labeled GSH, HomoCySH, CoA and $\mathrm{CySH}$ were eluted in that order respectively almost within $15 \mathrm{~min}$. The separation of ANS and these NAMlabeled four thiols was satisfactory with the elution condition (I) [Fig. 2(a), (b)]. Although the $R t$ of ANS and GSH was closer in the elution condition (I) than in (II), it gave no error in the practical analysis. In the elution condition (II) ANS was separated from GSH clearly but $\mathrm{CoA}$ was not separated from CySH [Fig. 2(c), (d)]. The elution condition (II) might be more convenient in the samples without $\mathrm{COA}$ as in the case of the tissues and blood.

\section{Calibration curves}

The determinations were made by measuring the peak height ratios of GSH and the peak area ratios of $\mathrm{CySH}$ to ANS. Figure 3 illustrates the calibration curves for GSH and CySH. Linear relationships were obtained in the wide range from $2.5 \mathrm{pmol}$ to $2.5 \mathrm{nmol}$ for GSH and $11 \mathrm{pmol}$ to $2.7 \mathrm{nmol}$ for $\mathrm{CySH}$. The standard deviations of the mean values were $2.7 \%$ for $\mathrm{GSH}$ and $2.3 \%$ for $\mathrm{CySH}$.

Preparation and analytical procedures of the biological samples

Rats ( $6 \sim 7$ months of age) were anesthetized with ether. Blood was collected from the heart with a heparinized syringe. Tissues were frozen immediately in a dry-ice acetone bath and stored at $-20^{\circ} \mathrm{C}$. The following preparative procedures are conveniently disigned for the determinations in tables.

Blood; $25 \mu \mathrm{l}$ of blood was added to $225 \mu \mathrm{l}$ of $0.02 \mathrm{M}$ EDTA and $50 \mu \mathrm{l}$ of $30 \%(\mathrm{w} / \mathrm{v})$ $\mathrm{HPO}_{3}$ was added in a glass tube $(5 \mathrm{~cm} \times 6 \mathrm{~mm}$ I.D.) to give a final concentration of $5 \%$. After the hemolysis, the solution was centrifuged at $4000 \mathrm{rpm}$ for $15 \mathrm{~min}$ at $4^{\circ} \mathrm{C}$. In another run, $50 \mu \mathrm{l}$ of blood, $200 \mu \mathrm{l}$ of $0.02 \mathrm{M}$ 
(A)

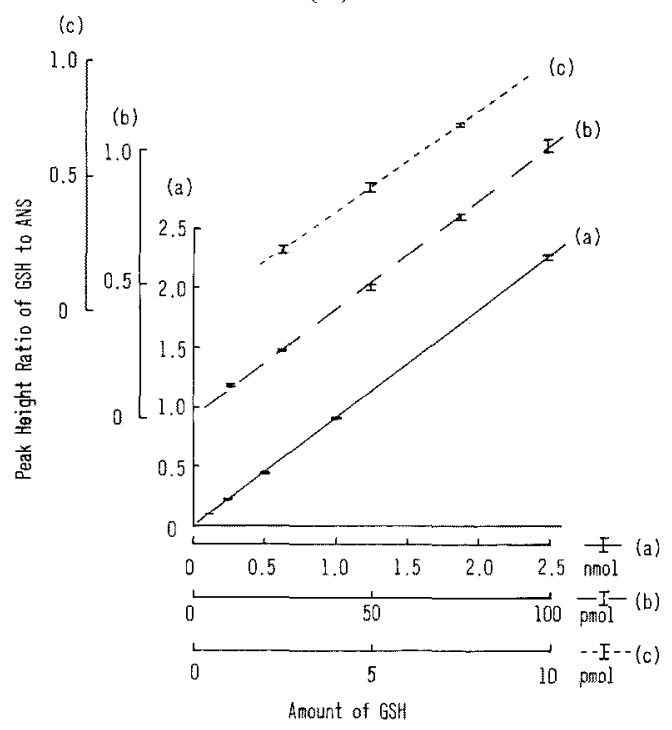

(B)

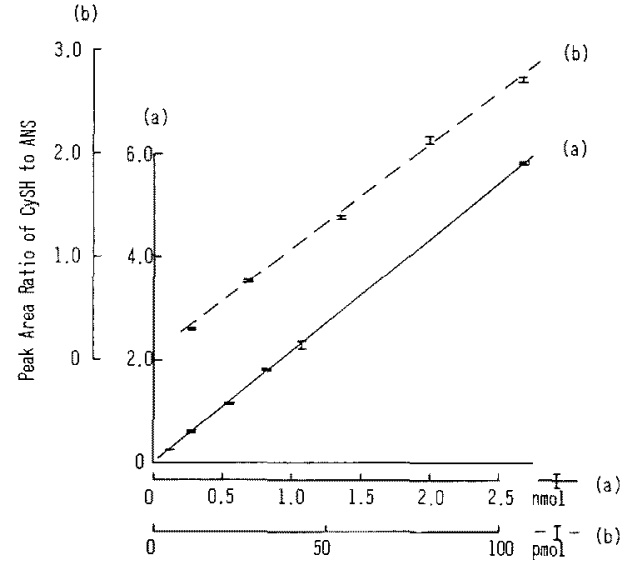

Amount of Cysh

FIG. 3. Calibration Curves for GSH (A) and CySH (B).

Series of the standard solutions of GSH (a, $0.05 \sim$ $1.24 \mu \mathrm{mol} / \mathrm{ml} ; \mathrm{b}, 5 \sim 50 \mathrm{nmol} / \mathrm{ml} ; \mathrm{c}, 0.5 \sim 5 \mathrm{nmol} / \mathrm{ml}$ ) and CySH (a, 0.06 1.34 $\mu \mathrm{mol} / \mathrm{ml} ; b, 5.5 \sim 55 \mathrm{nmol} /$ $\mathrm{ml})$ were prepared. The standard solutions $(20 \mu 1)$ were added to $60 \mu \mathrm{l}$ of the reaction buffer followed by the addition of $10 \mu \mathrm{l}$ of ANS and $10 \mu \mathrm{l}$ of NAM. ANS and NAM were added according to the concentration of thiols such as NAM $=3.8 \mu \mathrm{mol} / \mathrm{ml}$, ANS $=$ $2.06 \mu \mathrm{mol} / \mathrm{ml}$ for the series a, NAM $=0.19 \mu \mathrm{mol} / \mathrm{ml}$, ANS $=0.206 \mu \mathrm{mol} / \mathrm{ml}$ for the series $\mathrm{b}$ and $\mathrm{NAM}=$ $19 \mathrm{nmol} / \mathrm{ml}$, ANS $=20.6 \mathrm{nmol} / \mathrm{ml}$ for the series $\mathrm{c}$, respectively.
EDTA and $50 \mu \mathrm{l}$ of $30 \% \mathrm{HPO}_{3}$ were used. This supernatant was used for the determination.

Liver; $5 \mathrm{mg}$ of liver perfused with saline was homogenized in a Potter-Elvehjem type glass homogenizer with $245 \mu$ of $0.02 \mathrm{M}$ EDTA and $50 \mu \mathrm{l}$ of $30 \% \mathrm{HPO}_{3}$ with ice cooling. Precipitated proteins were centrifuged off in a similar manner to the case of blood, and this supernatant was used for the determination. Kidney and spleen; $10 \mathrm{mg}$ of kidney or spleen samples were treated in a similar manner to the case of liver.

Analytical procedure; the supernatant $(10 \mu \mathrm{l})$ was neutralized with $1 \mu 1$ of $5 \mathrm{~N} \mathrm{NaOH}$ in a glass tube $(5 \mathrm{~cm} \times 6 \mathrm{~mm}$ I.D. $)$. Then, $30 \mu \mathrm{l}$ of the reaction buffer, $2 \mu \mathrm{l}$ of $0.02 \mathrm{M}$ EDTA, $2 \mu \mathrm{l}(2 \mathrm{nmol}, 4.20 \mathrm{mg} / 10 \mathrm{ml})$ of ANS, $5 \mu \mathrm{l}$ ( $3 \mathrm{nmol}, 1.7 \mathrm{mg} / 10 \mathrm{ml}$ ) of NAM were added. After standing for $3 \mathrm{hr}, 10 \mu \mathrm{l}$ of the reaction mixture was injected on the column.

(a) Determination by the calibration curve method; to adjust the reaction conditions, a blank solution which contained equimolar amounts of EDTA and $\mathrm{HPO}_{3}$ was used instead of the supernatant of the sample solutions. A series of standard solutions were prepared by adding $2 \mu \mathrm{l}(0.1 \sim 1 \mathrm{nmol})$ of GSH $(1.54 \mathrm{mg}$ ) $10 \mathrm{ml}, 1 \mathrm{nmol} / 2 \mu \mathrm{l})$ or CySH $(1.21 \mathrm{mg} / 20 \mathrm{ml}$, $1 \mathrm{nmol} / 2 \mu \mathrm{l}$ ) into $10 \mu \mathrm{l}$ of the blank solution in a glass tube and reacted in the same way to the analytical procedure of samples.

(b) Determination by the standard addition method; sample preparations and analytical procedures were almost the same as in the previous paper ${ }^{8)}$ except the uses of $\mathrm{HPO}_{3}$ as a deproteinizing reagent and of $5 \mathrm{~N} \mathrm{NaOH}$ for the neutralization of the supernatant of the samples.

\section{Reliability of the method}

In order to check the accuracy and the precision of the method, the values obtained from the calibration curves were compared with those of the standard addition method. Figure 4 shows the linear relationships between the peak height ratios and the amount of GSH added in blood, spleen and liver. By extra- 
Table I. Thiol Contents in Rat Blood and Tissues by HPLC Method Elution condition (I)

\begin{tabular}{|c|c|c|c|c|c|}
\hline \multirow{2}{*}{ Sample } & \multirow{2}{*}{ Sample size ${ }^{a}$} & \multicolumn{4}{|c|}{ GSH Content } \\
\hline & & Calibration curve method & c.v. ${ }^{b}$ & Standard addition method & c.v. ${ }^{b}$ \\
\hline \multirow[t]{2}{*}{ Blood } & $25 \mu \mathrm{l}$ & $1.03 \mathrm{mmol} / \mathrm{liter}$ & 1.20 & $1.04 \mathrm{mmol} /$ liter & 0.80 \\
\hline & $50 "$ & 0.91 & 1.03 & 0.94 & 0.67 \\
\hline \multirow[t]{2}{*}{ Liver } & $5 \mathrm{mg}$ & $2.86 \mu \mathrm{mol} /$ wet g & 1.49 & $2.86 \mu \mathrm{mol} / \mathrm{wet} \mathrm{g}$ & 1.22 \\
\hline & $7 n$ & 2.87 & 1.24 & - & - \\
\hline Spleen & $10 \pi$ & 1.04 & 1.93 & 1.05 & 1.95 \\
\hline Kidney & $10 "$ & 0.41 & 1.61 & 0.42 & 1.75 \\
\hline \multicolumn{6}{|c|}{ Elution condition (II) } \\
\hline \multirow{2}{*}{ Sample ${ }^{c}$} & \multirow{2}{*}{ Sample size ${ }^{a}$} & \multicolumn{4}{|c|}{ CySH or GSH Content } \\
\hline & & Calibration curve method & c.v. ${ }^{b}$ & Standard addition method & c.v. ${ }^{b}$ \\
\hline & & GSH & & GSH & \\
\hline Blood & $25 \mu 1$ & $1.14 \mathrm{mmol} / \mathrm{liter}$ & 1.61 & $1.15 \mathrm{mmol} / \mathrm{liter}$ & 2.20 \\
\hline Liver & $5 \mathrm{mg}$ & $3.21 \mu \mathrm{mol} /$ wet $\mathrm{g}$ & 0.99 & $3.24 \mu \mathrm{mol} /$ wet $\mathrm{g}$ & 1.38 \\
\hline \multirow[t]{2}{*}{ Spleen } & $10 "$ & $1.44 \quad "$ & 1.60 & $1.40 \quad " \prime$ & 1.32 \\
\hline & & $\mathrm{CySH}$ & & $\mathrm{CySH}$ & \\
\hline Kidney & $10 "$ & 2.30 & 1.29 & 2.31 & 1.72 \\
\hline
\end{tabular}

a Sample size means the sample amount employed at the sample preparation procedure.

$b$ Coefficient of variation on the measurement $(n=3 \sim 4)$.

c Different samples were used in the elution condition (I) and (II).

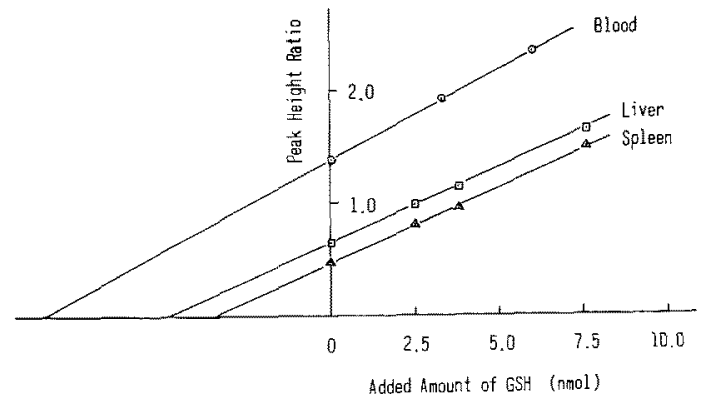

Fig. 4. Linear Relationships between the Peak Height Ratio of GSH to ANS and the Added Amounts of GSH in the Reaction Mixtures.

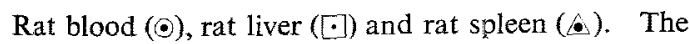
experiments were performed with the elution condition (I).

porations the thiol contents were obtained and are shown in Table I. There was no difference between the GSH contents or $\mathrm{CySH}$ content obtained from the calibration curve method and from the standard addition method. For the comparison of the present method, the same samples were analyzed by the traditional DTNB method (Table II). They also gave the same values. The elution conditions (I)

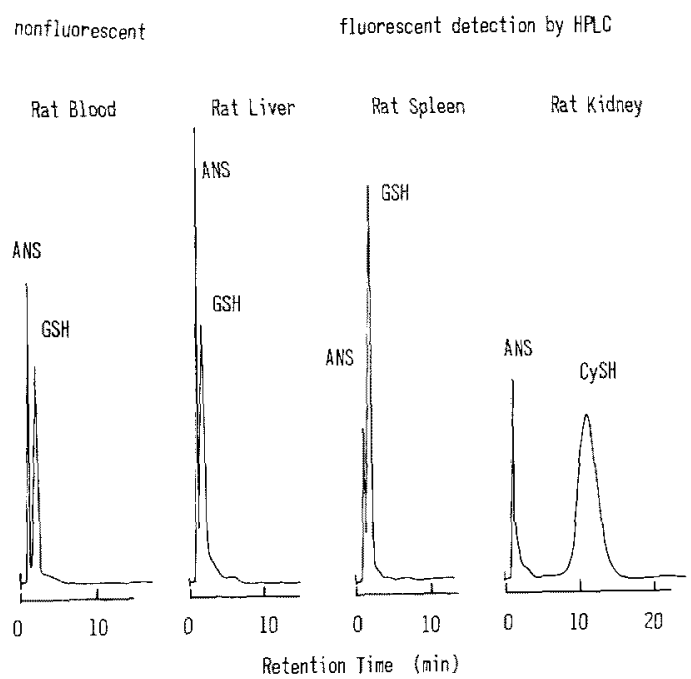

FIG. 5. High Performance Liquid Chromatograms of NAM-Labeled Blood and Mammalian Tissues.

Approximate amounts of samples injected on the column were $0.17 \mu \mathrm{l}$ of rat blood, $0.03 \mathrm{mg}$ of rat liver, $0.07 \mathrm{mg}$ of rat spleen and rat kidney. The experiments were performed with the elution condition (II).

and (II) also gave the same results with the standard deviation of $2 \sim 3 \%$.

Figure 5 represents chromatograms of ANS 
Table II. Comparison of the Present Method with DTNB Method

Elution condition ( $\mathrm{I})$

\begin{tabular}{|c|c|c|c|c|c|c|c|}
\hline \multirow{3}{*}{ Sample } & \multicolumn{6}{|c|}{ Thiol content } & \multirow{3}{*}{ Unit } \\
\hline & \multicolumn{4}{|c|}{ Present method ${ }^{a}$} & \multicolumn{2}{|c|}{ DTNB Method ${ }^{b}$} & \\
\hline & GSH & CySH & Sum & c.v. ${ }^{\circ}$ & Total & c.v. ${ }^{e}$ & \\
\hline Liver & 3.96 & 0 & 3.96 & 1.74 & 3.62 & 0.43 & $\mu \mathrm{mol} /$ wet g \\
\hline Kidney & 0.74 & 2.58 & 3.32 & 1.92 & 3.21 & 1.06 & $"$ \\
\hline \multicolumn{8}{|c|}{ Elution condition (II) } \\
\hline \multirow{3}{*}{ Sample ${ }^{d}$} & \multicolumn{6}{|c|}{ Thiol content } & \\
\hline & \multicolumn{4}{|c|}{ Present method ${ }^{a}$} & \multicolumn{2}{|c|}{ DTNB method ${ }^{b}$} & Unit \\
\hline & GSH & CySH & Sum & c.v. ${ }^{\circ}$ & Total & c.v. ${ }^{c}$ & \\
\hline Blood & 1.14 & 0 & 1.14 & 1.61 & 1.22 & 0.91 & $\mathrm{mmol} /$ liter \\
\hline Liver & 3.21 & 0 & 3.21 & 0.99 & 3.19 & 0.51 & $\mu \mathrm{mol} /$ wet $\mathrm{g}$ \\
\hline Spleen & 1.44 & trace & 1.44 & 1.60 & 1.61 & 1.48 & $"$ \\
\hline Kidney & trace & 2.30 & 2.30 & 1.29 & 2.49 & 1.22 & " \\
\hline \multicolumn{8}{|c|}{ a Obtained by the calibration curve method. } \\
\hline \multicolumn{8}{|c|}{$b$ Obtained by a modified DTNB method. ${ }^{8)}$} \\
\hline \multicolumn{8}{|c|}{ c Coefficient of variation on the measurement $(n=3 \sim 4)$. } \\
\hline \multicolumn{8}{|c|}{$d$ Different samples were used in the elution condition (I) and (II). } \\
\hline
\end{tabular}

and NAM-labeled biological samples obtained under the elution condition (II). No background fluorescent peak was observed in blood and tissue extracts. Blood, liver and spleen extract gave a large GSH peak. On the other hand, kidney extract gave a large $\mathrm{CySH}$ peak.

9-Aminoacridine can also be used as an internal standard, if a gradient attachment is available. However, on the single solvent elution method, ANS gave also the same results.

\section{Sensitivity of the method}

In the determination of the thiol contents, the net sample sizes injected on the HPLC were $0.17 \mu \mathrm{l}$ of blood, $0.03 \mathrm{mg}$ of liver and $0.07 \mathrm{mg}$ of kidney and spleen which were equivalent to about $0.1 \sim 0.2 \mathrm{nmol}$ of $\mathrm{GSH}$ or CySH. Considering the lower detection limit ( $2.5 \mathrm{pmol}$ ) of the calibration curve, it might be possible to reduce the present sample size.

The sensitivity of the method was higher than the current chemical method, Tabor's method, ${ }^{6)}$ using an automatic amino acid analyzer with the ninhydrin detector (the limit of the detection of GSH was $10 \mathrm{nmol}$ ) and the $o$-phthalaldehyde method for GSH $(2 \sim 5$ nmol). ${ }^{11}$ The sensitivity was almost equivalent to the enzymatic method for GSH reported by Koivusalo $(0.2 \mathrm{nmol})^{12)}$ and far more sensitive than the method of Tietze $(12 \mathrm{nmol}){ }^{13}$ )

In conclusion, NAM-labeled GSH, Homo$\mathrm{CySH}, \mathrm{CoA}$ and $\mathrm{CySH}$ were separated on the HPLC within $15 \mathrm{~min}$ and linear relationships obtained between the amounts of GSH or CySH and the peak height or area ratio of their NAM derivatives to ANS in the wide and low concentration ranges. The procedures were simple and accurate.

\section{REFERENCES}

1) A. Fontana and C. Tonielo, "The Chemistry of the Thiol Group," ed. by S. Patai, part I, chapter 5, John Wiley \& Sons, 1974, p. 271.

2) P. C. Jocelyn, "Biochemistry of the SH Group," Academic Press, New York, 1972, p. 137.

3) S. Clowick, A. Lazarow, E. Racker, D.R.Schmartz, E. Stadtman and H. Waelsch, Ed., "Glutathione," Academic Press, New York, 1954, p. 63.

4) G. L. Ellman, Arch. Biochem. Biophys., 82, 70 (1959).

5) E. Roberts and G. Rouser, Anal. Chem., 30, 1219 (1958).

6) C. W. Tabor and H. Tabor, Anal. Biochem., 45, 543 (1977).

7) D. L. Rabenstein and R. Saltre, Anal. Chem., 45, 
1036 (1977).

8) H. Takahashi, Y. Nara and K. Tuzimura, Agric. Biol. Chem., 42, 769 (1978).

9) Y. Nara and K. Tuzimura, Bunseki Kagaku, 22, 451 (1973).

10) Y. Nara and K. Tuzimura, Agric. Biol. Chem., 42 ,
793 (1978).

11) P. J. Hissin and R. Hilf, Anal. Biochem., 74, 214 (1976).

12) M. Koivusalo and L. Uotila, Anal. Biochem., 59, 34 (1974).

13) F. Tieze, Anal. Biochem., 27, 502 (1969). 